\title{
Pengaruh Penerapan Model Pembelajaran Problem Solving Pada Kemampuan Berpikir Kritis Mahasiswa
}

\author{
Jalilah Azizah Lubis \\ ${ }^{1}$ Program Studi Pendidikan Biologi FKIP Universitas Muhammadiyah Tapanuli Selatan, \\ Jalan Sutan Mohammad Arief No. 32 Padangsidimpuan, 22719, Indonesia \\ Email: jalilah_azizah@ymail.com
}

\begin{abstract}
Abstrak: Penelitian ini bertujuan untuk mengetahui perbedaan hasil belajar (tinggi dan rendah), kemampuan berpikir kritis (tinggi dan rendah) mahasiswa antara yang menggunakan model pembelajaran problem solving dan pembelajaran langsung berbantuan media camtasia dengan video pembelajaran. Penelitian ini menggunakan metode eksperimen dengan populasi penelitian adalah mahasiswa semester VI Universitas Muhammadiyah Tapanuli Selatan Tahun Pelajaran 20 sampel penelitian sebanyak 2 kelas yang ditentukan dengan teknik cluster random sampling yaitu 1) Kelas yang dibelajarkan dengan metode pembelajaran langsung, 2) Kelas yang dibelajarkan dengan model pembelajaranan Problem Solving. Instrumen penelitian menggunakan tes kemampuan berpikir kritis sebanyak 15 soal, tes hasil belajar sebanyak 25 soal dalam bentuk pilihan berganda yang telah di uji validitas, reliabilitas, daya beda. Teknik analisis menggunakan uji-T. Dari hasil analisis data dan pengujian hipotesis dapat diketahui bahwa : 1) Hasil belajar mahasiswa yang dibelajarkan dengan perlakuan metode langsung dan video pembelajaran secara signifikan lebih tinggi dibandingkan dengan hasil belajar perlakuan yang lain. 2) Kemampuan berpikir kritis mahasiswa dengan perlakuan metode langsung dan video pembelajaran secara signifikan lebih tinggi dbandingkan dengan hasil belajar perlakuan yang lain. Media pembelajaran sebagai pengantar pesan yang terbaik adalah video pembelajaran karena dapat media ini temasuk pada media audio visual yang dapat merangsang pendengaran dan penglihatan dan mahasiswa lebih efektif dalam memahami langkah - langkah pembuatan media tumbuh secara langsung. Sebagai tindak lanjut dari hasil penelitian ini diharapkan kepada guru untuk dapat menerapkan video pembelajaran dalam proses pembelajaran langsung maupun problem solving dalam upaya meningkatkan aktivitas belajar dan menumbuh kembangkan kemampuan berpikir kritis siswa sehingga mahasiswa dapat memperoleh hasil belajar yang maksimal.
\end{abstract}

Kata Kunci: Model Pembelajaran, Hasil Belajar, Kemampuan Berpikir Kritis

\section{PENDAHULUAN}

Pembelajaran biologi dalam perguruan tinggi dapat diartikan sebagai kegiatan yang ditujukan untuk meningkatkan hasil belajar, kemampuan berpikir kritis, pengetahuan, keterampilan sikap dan nilai. Penerapan proses belajar mengajar di Indonesia kurang mendorong pada pencapaian kemampuan berpikir kritis. Proses pembelajaran di ruangan diarahkan kepada kemampuan untuk menghafal informasi yang hanya didapatkan dari dosen. Kemampuan berpikir kritis dapat digunakan sebagai modal intelektual yang sangat penting untuk kematangan manusia. Oleh karena itu, pengembangan berpikir kritis manjadi sangat penting bagi dijenjang pendidikan. Pendidikan biologi bertujuan untuk membantu dalam mengembangkan suatu pemahaman konsep dan berpikir kritis yang bermakna dan membuat mahasiswa mengetahui bagaimana konsep tersebut dapat digunakan dalam kehidupan sehari-hari .

Berdasarkan pengamatan ditemukan masalah pada hasil belajar mahasiswa di Universitas Muhammadiyah Tapanuli Selatan
Kota Padangsidimpuan. Dimana media yang digunakan pada saat pembelajaran masih berupa media visual dengan menggunakan LCD, sehingga diperlukan pengembangan media dalam bentuk audio - visual yang dapat meningkatkan kemampuan berpikir kritis, hasil belajar mahasiswa dan minat mahasiswa dalam belajar. Dua faktor penyebab kurang berkembangnya kemampuan berpikir kritis selama ini disebabkan kurikulum yang umumnya dirancang dengan target mata kuliah yang luas sehingga pengajar lebih terfokus pada penyelesaian mata kuliah dan kurangnya pemahaman pengajar dalam meningkatkan kemampuan berpikir kritis.

Permasalahan lainnya yang ditemukan adalah rendahnya kemampuan berpikir kritis mahasiswa yang terlihat dari kualitas pertanyaan dan jawaban pada saat proses pembelajaran berlangsung. Mahasiswa kurang mampu menggunakan daya nalar dalam menanggapi informasi yang diterimanya. Dari DPNA mahasiswa pendidikan biologi pada mata kuliah kultur jaringan tanaman dalam tiga tahun terakhir didapatkan hasil pembelajaran biologi pada tiga tahun terakhir didapatkan 
nilai mahasiswa yang belum semua mencapai nilai baik, ini disebabkan karena terbatasnya menyampaikan mata kuliah dan media pembelajaran masih sedikit mempergunakan video pembelajaran sehingga belum dapat meningkatkan berpikir kritis mahasiswa.

Ilmu pengetahuan di bidang sains khususnya biologi, salah satunya ilmu tentang kultur jaringan tanaman yang dibelajarkan di Universitas Muhammdiyah Tapanuli Selatan diharapkan dapat dipahami mahasiswa dan diaplikasikan dalam mengeksploitasi suatu tanaman untuk beregenerasi dengan sangat pesat dan mampu diatur sesuai dengan kebutuhan manusia modern seperti saat ini, maka kultur jaringan merupakan salah satu cabang dari ilmu biologi yang sangat perlu untuk dikembangkan dewasa ini khususnya di Indonesia dengan menggunakan media audiovisual. Namun, kenyataannya mata kuliah ini hanya diberikan SKS yang sedikit sehingga pembelajaran yang dilakukan hanya teori saja dengan pembelajaran langsung tanpa dilaksanakan praktikum yang hanya menggunakan media sederhana yaitu menggunakan Liquid Crystal Display (LCD) Hal ini berdampak pada pengetahuan, kemampuan berpikir kritis dan kecakapan dalam memahami kultur jaringan secara komperhensif.

Berdasarkan penelitian yang dilakukan oleh Achmad Waris yang bertujuan untuk mengetahui manfaat media VCD Pembelajaran tentang sifat dan perubahan wujud benda dalam proses belajar siswa khususnya mata pelajaran Sains mata kuliah sifat dan perubahan wujud benda. Kesimpulan penelitian menunjukkan bahwa perlakuan dengan menggunakan media VCD Pembelajaran lebih efektif meningkatkan hasil belajar dibandingkan dengan yang tidak menggunakan media VCD Pembelajaran pada siswa. Untuk tujuan afektif dapat menggunakan efek dan teknik, video dapat menjadi media yang sangat, baik dalam mempengaruhi sikap dan emosi. Untuk tujuan psikomotorik video merupakan media yang tepat untuk memperlihatkan contoh ketrampilan yang menyangkut gerak. Dengan alat ini dijelaskan, baik dengan cara memperlambat maupun mempercepat gerakan yang ditampilkan. Melalui video siswa dapat langsung mendapat umpan balik secara visual terhadap kemampuan mereka sehingga mampu mencoba ketrampilan yang menyangkut gerakan tadi.

Hasil pembelajaran biologi di perguruan tinggi diharapkan dapat membantu proses penguasaan konsep biologi, berpikir kritis, kreativitas, kemampuan memecahkan masalah, sikap, dan keterampilan berkomunikasi. Levie \& Levie menyatakan bahwa belajar melalui stimulus gambar atau visual membuahkan hasil belajar yang lebih baik untuk tugas-tugas seperti mengingat dan mengenali kembali.

Permasalahan tersebut akan diselesaikan dengan menerapkan model pembelajaran problem solving dan menggunakan media video pembelajaran dan camtasia sehingga dapat menngkatkan kemampuan berpikir kritis dan hasil belajar mahasiswa, karena dengan adanya model pembelajaran problem solving mahasiswa lebih terpacu untuk menyelesaikan masalah yang diberikan baik secara individu maupun berkelompok yang dibantu dengan media video pembelajaran dalam memahami materi kultur jaringan pokok bahasan pembuatan media. Kegiatan problem solving melatih mahasiswa untuk mendesain suatu penemuan, 2. Berpikir dan bertindak kreatif, 3. Memecahkan masalah yang dihadapi secara realistis, 4. Mengidentifikasi dan melakukan penyelidikan, 5. Menafsirkan dan mengevaluasi hasil pengamatan, 6. Merangsang perkembangan kemajuan berpikir mahasiswa untuk menyelesaikan masalah yang dihadapi dengan tepat, 7. Membuat pendidikan sekolah lebih relevan dengan kehidupan khususnya dunia kerja. Dalam materi kultur jaringan sebenarnya lebih banyak berhubungan dengan percobaan langsung karena dengan mahasiswa dapat lebih aktif melihat proses pembuatan media tersebut dan lebih meningkatkan keterampilan berpikir kritis dimana keterampilan berpikir tingkat tinggi yang berpotensi meningkatkan daya analitis kritis siswa dan memperkuat pemahaman konsep mahasiswa.

\section{METODE PENELITIAN}

Metode yang digunakan dalam penelitian ini adalah quasi eksperimen semu (Quasi Eksperimental Research) dengan melibatkan dua kelompok yaitu eksperimen satu dengan problem solving dan eksperimen dua dengan pembelajaran langsung. Populasi dalam penelitian ini adalah mahasiswa biologi semester VI angkatan 2008 jurusan biologi Fakultas Keguruan Ilmu Pendidikan (FKIP) Universitas Muhammadiyah Tapanuli Selatan yang diambil sebanyak 2 kelas. Teknik pengambilan sampel ditetapkan dengan teknik Cluster Random sampling yaitu secara acak dua kelas. Desain yang digunakan dalam penelitian ini adalah desain faktorial pretest - 
postest control group design. Penelitian ini membandingkan pretes hasil belajar, dengan postest hasil belajar setelah diberikan perlakuan dan pengaruh metode pembelajaran langsung dan problem solving dengan menggunakan video pembelajaran dan Camtasia terhadap hasil belajar kultur jaringan dan kemampuan berpikir kritis.

Instrumen yang digunakan berupa instrumen pelaksanaan pembelajaran berupa silabus, satuan acuan perkuliahan, LKS dan instrumen pengambilan data berupa tes hasil belajar, tes kemampuan berpikir kritis dan angket aktivitas. Teknik pengumpulan data untuk mengukur hasil belajar dengan satu jawaban yang benar dan tes dilaksanakan sebanyak 2 kali, yaitu pretest yang bertujuan untuk memperoleh tingkat kemampuan awal dan postest untuk mengukur hasil akhir belajar . Teknik pengumpulan data berpikir kritis menggunakan test berpikir kritis Cornell (CCTTS) dimodifikasi. Sebelum dijadikan instrumen pengumpul data, dilaksanakan uji validitas isi dan validitas konstruk yang telah disusun oleh ahli ( Dosen kultur jaringan).

Teknik analisis data menggunakan hasil belajar mahasiswa dan kemampuan berpikir kritis menggunakan tekhnik analisis data yang digunakan adalah $u j i-T$ dua jalur pada tahap yang signifikan $\alpha 5 \%$. Apabila hasil analisis $\mathrm{F}_{\text {hitung }}<\mathrm{F}_{\text {tabel }}$ menunjukkan perbedaan yang signifikan. Beberapa persyaratan yaitu : 1) Data yang diharapkan harus berdistribusi normal, dan 2) Data harus memiliki varians populasi homogen. Untuk menguji normalitas data digunakan uji Kolmogrov - Smirnov pada taraf signifikan 0,05 . Uji homogenitas varians data menggunakan levene's pada taraf signifikan 0,05. Data dianalisis dengan menggunakan $\begin{array}{llll}\text { SPSS } & 19.0 \quad \text { for windows. }\end{array}$

\section{HASIL DAN PEMBAHASAN}

Tabel 1.Analisis data keseluruhan perlakuan pada pretes - postes

\begin{tabular}{cccccc}
\hline Perlakuan & Mean & Median & Nilai min & Nilai maks & Standard deviasi \\
\hline Postes Kemampuan & 74,77 & 74,00 & 47 & 100 & 10,99 \\
Pretes Kemampuan & 66,04 & 64,00 & 44 & 92 & 10,65 \\
\hline
\end{tabular}

\section{Pengaruh model pembelajaran terhadap kemampuan berpikir kritis mahasiswa}

Dari analisis data kemampuan berpikir kritis mahasiswa dalam menyelesaikan masalah hal pembuatan media tumbuh yang tampak saat diberikan masalah untuk perorangan, selama proses pembelajaran para mahasiswa tampak aktif dalam kegiatan pembelajaran serta aktif bertanya, karena jarang menggunakan metode pembelajaran problem solving dengan media video pembelajaran selama melaksanakan proses pembelajaran, jadi mahasiswa lebih aktif dalam belajar di kelas saat metode langsung berlangsung para mahasiswa tampak lebih berani dan lebih kritis dalam bertanya maupun mengungkapkan ide atau pendapatnya pribadi serta mempertahankan pendapatnya pada saat sesi tanya jawab.

Hasil antara langsung dan video dan problem solving dan video pembelajaran, selama pembelajaran, dapat dilihat dari grafik dimana mahasiswa memiliki tugas membahas masalah yang diberikan pada saat pembelajaran berlangsung kegiatan ceramah dan sesi tanya jawab lebih aktif dibanding dengan problem solving karena pada saat diskusi mahasiswa hanya berpegang pada 1/3 anggota kelompok yang aktif mengerjakan soal karena didalam anggota kelompok yang heterogen. Sementara kelompok siswa yang diajarkan dengan model pembelajaran langsung dimana proses pembelajaran cenderung berpusat pada mahasiswa menggunakan metode ceramah dan buku yang ada menjadikan mahasiswa tampak lebih semangat dalam belajar dan mampu mengembangkan kemampuan berpikir kritisnya selama mengamati video pembelajaran karena di dalam video sudah dapat terlihat jelas proses dan tahap - tahap yang dibutuhkan dalam kultur jaringan, dan pada metode langsung dan camtasia mahasiswa aktif dalam proses pembelajaran hanya tidak aktif dalam pengamatan camtasia, karena walaupun ada bagian yang kurang jelas mahasiswa tidak menanyakan kembali bagian tesebut dalam sesi tanya jawab, dan pada metode ceramah mahasiswa lebih aktif merespon media sehingga mahasiswa dapat memahaminya kembali.

Selama proses pembelajaran problem solving tampak hanya beberapa siswa yang mau dan berani menjawab pertanyaan dan dosen hanya berperan sebagai fasilitator dalam proses pembelajaran. Ketika dosen memberikan pertanyaan dan meminta siswa untuk 
mengungkapkan pendapatnya, tampak hanya beberapa siswa yang mampu mengemukakan pendapatnya untuk menjawab pertanyaan yang diberikan dosen. Selama proses pembelajaran, kemampuan berpikir kritis siswa berpengaruh tetapi kurang dikembangkan, sehingga hasil kemampuan berpikir kritis mahasiswa tidak berbeda nyata pada metode pembelajaran tetapi pada penggunaan media kemampuan berpikir kritis mahasiswa berbeda ini teruji kebenarannya dalam perlakuan metode langsung dengan video pembelajaran dibandingkan dengan metode langsung dan camtasia, dikarenakan siswa lebih banyak belajar tergantung pada teman yang aktif dalam kelompok dengan menerima, mencatat, dan menghafal materi pelajaran yang diterimanya dari dosen sebagai fasilitator dalam jalannya proses pembelajaran.

Kesimpulan di atas, sekaligus mendukung teori yang dikemukakan Tyler dalam Redhana (2003), bahwa pengalaman atau pembelajaran yang memberikan kesempatan kepada siswa untuk memperoleh keterampilan-keterampilan dalam pemecahan masalah dapat merangsang keterampilan berpikir kritis siswa.

\section{Pengaruh pendekatan media video pembelajaran dan camtasia tehadap kemampuan berpikir kritis}

Dari hasil analisis data terlihat manfaat pendekatan pembelajaran dan media pembelajaran dimana video pembelajaran lebih efektif daripada media camtasia. Keefektifan video pembelajaran dalam meningkatkan kemampuan berpikir kritis teruji pada peningkatan kemampuan berpikir kritis yang menggunakan perlakuan A dan B yang memiliki $\mathrm{t}_{\text {hitung }}<\mathrm{t}_{\text {tabel }}(2,00<2,06)$ nilai juga sig. 0,05 pada taraf $\alpha 0,05$. Hal ini juga dapat dibuktikan dalam meningkatkan hasil belajar pada perlakuan $\mathrm{A}$ dan $\mathrm{C}$ yang memiliki $\mathrm{t}_{\text {hitung }}<$ $\mathrm{t}_{\text {tabel }}(3,84>2,06)$ yang dikuatkan dengan nilai sig. $0,000<\alpha 0,05$ serta perlakuan $C$ dan $D$ yang memiliki $t_{\text {hitung }}<t_{\text {tabel }}(3,23<2,06)$ yang dikuatkan dengan nilai sig.0,002 $<\alpha 0,05$ pada hasil belajar, ini dapat dinyatakan bahwa media pembelajaran merupakan suatu sarana yang bermanfaat untuk membantu proses komunikasi. Sehingga pesan atau informasi dapat diserap dan dipahami oleh para mahasiswa.

Menurut Anderson kelebihan video antar lain mahasiswa mendapatkan isi dan susunan yang masih utuh dari materi pelajaran serta pembelajaran dengan video merupakan suatu pembelajaran mandiri artinya peserta didik belajar sesuai dengan kecepatan masing masing memahami materi.

Menurut pakar Mell Silberman dalam Andi Prastowo (2011) yang mengungkapkan suatu data penelitian bahwa dengan menambahkan visual pada pelajaran dapat menaikkan ingatan $14 \%$ menjadi $38 \%$ penelitian ini juga sesuai dengan penelitian American Hospital Association ditemukan bahwa ajar video mempunyai kelebihan antara lain bermanfaat untuk meggambarkan gerakan,keterkaitan, dan memberikan dampak pada topik yang dibahas, dapat diputar ulang dan dapat pula dikombinasikan dengan teknik film lain seperti animasi, gambar diam. Dengan penggunaan video pembelajaran mahasiswa lebih mudah memahami langkah - langkah pembuatan media dan secara langsung diperlihatkan dalam video pembelajaran karena video dapat mengombinasikan dua materi yaitu materi visual dan materi auditif yang dapat merangsang alat indra mata dan pendengaran dan di dalam video sudah dikombinasikan gambar yang bergerak dengan audio secara efektif juga, secara langsung sehingga para siswa seperti berada di suatu tempat yang sama dengan program yang ditayangkan dan menciptakan proses pembelajaran yang lebih berkualitas karena komunikasi berlangsung secara efektif jika dibandingkan dengan camtasia yang hanya memperlihatkan tulisan yang menjelaskan tentang pembuatan media tanpa dipraktekan secara langsung pada media, Video pembelajaran termasuk dalam media audio visual dapat mempercepat pemahaman siswa dan peningkatan hasil belajar siswa, kemampuan berpikir kritis siswa, dibanding dengan camtasia yang termasuk dalam media visual, yang hanya menjelaskan proses pembuatan media.

Kesimpulan diatas sesuai dengan pendapat yang menyatakan fungsi media dalam proses belajar yaitu sebagai alat bantu untuk mewujudkan situasi belajar yang efektif, dapat lebih menrik perhatian mahasiswa, membantu untuk mempercepat proses belajar mengajar, membantu mahasiswa dalam memahami dan meningkatkan dan mempertinggi mutu belajar, mengurangi terjadinya verbalitas dan memperbesar minat siswa dan memberikan pengalaman yang nyata bagi mahasiswa. Sedangkan penggunakan media VCD Pembelajaran lebih efektif meningkatkan hasil belajar dibandingkan dengan yang tidak menggunakan media VCD Pembelajaran pada siswa (Achmad, 2009). De Porter (2000:214) 
juga mengungkapkan manusia dapat menyerap suatu pesan sebanyak 50\% dari apa yang didengar dan dilihat, sedangkan yang dilihat hanya $30 \%$ saja. Sehingga dapat disimpulkan bahwa penggunaan metode yang bervariasi dan penggunaan media yang tepat dapat memberikan konstribusi dalam pencampaian hasil belajar yang maksimal. Media dapat berfungsi mengurangi pemahaman verbal mahasiswa dan mengarah kepada kemampuan yang lebih aktif.

\section{SIMPULAN}

Hasil belajar mahasiswa yang dibelajarkan dengan model pembelajaran langsung dan video dan langsung dan camtasia tidak terlalu berbeda nyata karena masalah yang diberikan pada postest sudah pernah diujikan pada pretest. Dalam hal ini hasil belajar yang lebih baik itu terletak pada perlakuan metode langsung dan ceramah, langsung dan camtasia, problem solving dan video pembelajaran dan problem solving dan camtasia. Kemampuan berpikir kritis siswa yang dibelajarkan dengan model pembelajaran langsung dan video pembelajaran pada materi pembuatan media tumbuh secara signifikan 9,4\% lebih tinggi dibandingkan dengan siswa yang dibelajarkan dengan pembelajaran langsung dan camtasia, meskipun perbedaan ini tidak terlalu besar, tetapi kemampuan berpikir kritis kelompok siswa yang dibelajarkan dengan model pembelajaran problem solving dan camtasia kurang berkembang dengan adanya diskusi yang hanya berpatok pada mahasiswa yang aktif dalam kelompok dan proses pembelajaran ini jarang di aplikasikan di lapangan. Sedangkan ceramah sangat membantu siswa dalam memahami bagian - bagian yang tidak paham pada proses pembelajarannya yang berpusat pada dosen. Penggunaan media video pembelajaran lebih mudah dipahami oleh mahasiswa daripada media camtasia disebakan dalam menggunakan video pembelajaran mahasiswa lebih mudah memahami langkah - langkah pembuatan media dan secara langsung diperlihatkan dalam video pembelajaran karena video dapat mengombinasikan dua materi yaitu materi visual dan materi auditif yang dapat merangsang alat indra mata dan pendengaran dan di dalam video sudah dikombinasikan gambar yang bergerak dengan audio secara efektif juga,secara langsung sehingga para siswa seperti berada disuatu tempat yang sama dengan program yang ditayangkan dan menciptakan proses pembelajaran yang lebih berkualitas karena komunikasi berlangsung secara efektif dan pada video sudah tertera lebih lengkap proses pembuatan media tumbuh secara praktek daripada menggunakan camtasia yang sangat perlu dipahami.

\section{DAFTAR PUSTAKA}

Anderson, L.W., and Krathwohl, D.R. 2001. A Taxonomy for Learning, Teaching and Assessing: A Revision of Bloom's Taxonomy of Educational Objectives, New York: Longman.

A. Lie. (2005). Cooperative Learning. Jakarta. Gramedia

Arsyad. 2005. Media Pembelajaran. Rajawali Press Indonesia. Jakarta.

Arends, R. I. 2008. Learning to Teach: Belajar untuk Mengajar. Buku Dua. (Penterjemah: Helly Prayitno Soetjipto dan Sri Mulyantini Soetjipto). Pustaka Pelajar. Yogyakarta.

Armstrong N., Chang S., Brickman M. 2007. Cooperative Learning in Industrial-Sized Biology Classes, CBE-Life Sciences Education, (6) 163-171.

Daryanto. 2009. Panduan Proses Pembelajaran Kreatif dan Inovatif. AV Publisher. Jakarta.

Ennis, R.H., et.all. 1964. Cornell Critical Thinking Test Series: The Cornell Conditional-Reasoning Test, Form X, Published by Illinois Critical Thinking Project, Departement of Educational Policy Studies, University of Illinois at UrbanaChampaign.

Gokhale, A. A. 2002. Collaborative Learning Enhances Critical Thinking, http://scholar.lib. vt.Edu/enjournals/JTE. Diakses 21 Desember 2010.

Harahap, F .2011. Kultur Jaringan. Unimed Pers. Medan

Hartono, 2008. Statistik Untuk Penelitian, Yogyakarta: Pustaka Pelajar.

Orclich, D.C., et al. 1998. Teaching Strategies. Boston New York: Houghton Mifflin Company.

Parveen Qaisara. Et all. (2011). Effect Of Cooperative Learning On Academic Achievement Of 8th Grade Students In The Subjectof Social Studies. Journal Pakistan Science Education. 3. (1). January, 2011, Part III

Prastowo Andi, 2011, Panduan Kreatif Membuat Bahan Ajar Inovatif Menciptakan Metode Pembelajaran yang Menarik Dan Menyenangkan, Diva press, Yogyakarta.

Redhana, I.W. 2003. Meningkatkan Keterampilan Berpikir Kritis Siswa Melalui Pembelajaran Kooperatif Dengan Strategi Pemecahan Masalah. Jurnal Pendidikan Dan Pengajaran XXXVI. II:11-21.

Slavin, R.L. 2008, Cooperative Learning, Theory, Research, and Practice, Second Edition, Library of Congress Cataloging-in-Publication Data, ISBN 0-205-15630-4 